\title{
SOURCES OF CARBON TO DEEP-SEA CORALS
}

\author{
SHEILA GRIFFIN and ELLEN R M DRUFFEL \\ Department of Chemistry \\ Woods Hole Oceanographic Institution \\ Woods Hole, Massachusetts 02543
}

\begin{abstract}
Radiocarbon measurements in deep-sea corals from the Little Bahama Bank were used to determine the source of carbon to the skeletal matrices. Specimens of Lophelia, Gerardia, Paragorgia johnsoni and Corallium noibe were sectioned according to visible growth rings and/or stem diameter. We determined that the source of carbon to the corals accreting organic matter was primarily from surface-derived sources. Those corals that accrete a calcerous skeleton were found to obtain their carbon solely from dissolved inorganic carbon (DIC) in sea water from the depth at which the corals grew. These results, in conjunction with growth-rate studies using short-lived radioisotopes, support the use of deep-sea corals to reconstruct time histories of transient and non-transient tracers at depth in the oceans.
\end{abstract}

\section{INTRODUCTION}

For more than 100 years, it has been known that corals exist in the very deep ocean (Pourtales, 1868). However, little is known about the carbon source to the skeleton or growth rate of these deep-sea corals. Most deepsea corals are azooxanthellate (Schuhmacher \& Zibrowius, 1985) and ahermatypic, ie, they are without symbionts and do not contribute significantly to the framework of coral reefs. These corals exist worldwide at all depths of the deep ocean and at temperatures as low as $-1.1^{\circ} \mathrm{C}$ (Vaughan \& Wells, 1943; Wells, 1956).

Of the known genera of deep-sea corals, about half are of solitary morphology. The rest are branching and have the ability to form deep-sea coral banks. The dominant genera that have been found to form banks are Madrepora, Lophelia, Sollenosmilia, Enallopsammia and Dendrophyllia, all of which accrete calcareous (calcium carbonate) skeletons. According to Mullins et al (1981), deep-sea coral banks in the North Atlantic form under different conditions than the more familiar hermatypic, surface coral reefs. The structures begin with a single colony, with a diameter of up to $1 \mathrm{~m}$. A group of colonies form a thicket and may be mono- or polytypic in composition. A coppice stage can come next, in which skeletal debris begins to accumulate, providing a substrate for new coral growth. At the end of this stage, a diverse benthic fauna is supported. The final stage is the formation of a bank, which reaches heights up to $50 \mathrm{~m}$, and is capped by living coral (Squires, 1964).

Few studies have addressed the growth rates of deep-sea corals. Duncan (1877) and Pratje (1924) reported growth rates for Lophelia of $0.68 \mathrm{~cm}$ to $0.75 \mathrm{~cm} / \mathrm{yr}$ based on coral growing on transatlantic cables. Teichert (1958) estimated values of $0.75 \mathrm{~cm}$ to $1.5 \mathrm{~cm} / \mathrm{yr}$ for Lophelia. Grigg (1974) reported a growth rate of $0.3 \mathrm{~cm} / \mathrm{yr}$ for Corallium japonicum, based on recovery of tagged colonies off Japan. Mikkelsen et al (1982) estimated the growth rate for Lophelia of $2.5 \mathrm{~cm} / \mathrm{yr}$ using oxygen isotope data. These are all growth rates based on linear extension of the branches.

Determining coral growth using direct observational methods is difficult because of the depth at which these corals grow. It is important, there- 
fore, to consider the development of radiometric methods for determining growth rates. In order for radiometric methods to be valid, it must be demonstrated that, once the coral skeleton is secreted, it remains a closed, unaltered system. Goreau and Goreau (1960), using a Ca-45 tracer, demonstrated that, once the skeleton of hermatypic corals is secreted, there is no exchange of calcium with the sea water. Studies of scleractinians (skeletal-building corals) indicate relatively little diagenetic alteration. Newton et al (1987), analyzed six Lophelia (an aragonitic species) samples from coral mounds on the West Florida Slope. The samples were dead when collected and all had ${ }^{14} \mathrm{C}$ ages $>40,000$ BP and all but the most corroded sample was still $100 \%$ aragonite. Sr levels in the Lophelia showed no significant difference from modern levels, and $\delta^{13} \mathrm{C}$ signatures characteristic of deep-sea ahermatypes were retained.

This study addresses primarily the source of carbon to the skeletal matrix and, to a minor extent, the growth rate of these deep-sea corals. Our measurements will be compared to growth-rate estimates of one of the specimens (Corallium) obtained from excess ${ }^{210} \mathrm{~Pb}$ measurements (Druffel \& King, $\mathrm{ms}$ in preparation). Ultimately, the skeletons may provide time histories of the penetration of transient tracers into the main thermocline $(0-$ $1000 \mathrm{~m}$ depth), which will be extremely useful for testing models that simulate processes such as the invasion and distribution of excess (fossil fuel and biospheric) $\mathrm{CO}_{2}$ in the oceans.

\section{SAMPLE COLLECTION AND METHODS}

The coral samples were collected west of the Little Bahama Bank in the Gulf Stream $\left(27^{\circ} 04^{\prime} \mathrm{N}, 79^{\circ} 20^{\prime} \mathrm{W}\right)$ during three dives on the $D S R / V$ Alvin (tender $R / V$ Lulu) in October 1982 (Fig 1). Mounds as high as 30m were observed at depths of $573-650 \mathrm{~m}$. Water temperature at the depth range of sample collection varied between $12.12^{\circ}$ and $12.80^{\circ} \mathrm{C}$. Current speed in this area varies from 0.2 to 3.0 knots (Sikes, 1984). Strong bottom currents, generally associated with modern coral banks, provide the corals with oxygen, food and nutrients. The Florida Current (Gulf Stream) is the dominant flow at this location. It is not known whether these particular mounds were lithified or unlithified (Mullins et al, 1981; Neumann, Kofold $\&$ Keller, 1977). Areas between the mounds are relatively flat and display sediment-starved ripple marks.

Five separate deep-sea coral samples were used for this study (Table 1): 2 Lophelia specimens, 1 white, 1 brown; 1 Gerardia specimen (Fig 2); 1 Paragorgia johnsoni and 1 Corallium noibe (Fig 3). All the corals examined in this study were living at the time of collection, except for the brown-colored Lophelia. All the samples, except the Corallium, were frozen immediately and then cleaned of living polyps at the Woods Hole Oceanographic Institution.

The Gerardia was arborescent in structure. The tips, stem and trunk were sectioned and analyzed separately. The specimen was defrosted and soaked for $20 \mathrm{~min}$ in a solution of $50 \%$ clorox bleach, and the polyps were removed with a small brush. After all the soft living tissue was removed, the sample was rinsed several times with distilled water and then dried in a $50^{\circ} \mathrm{C}$ oven overnight. Samples were sectioned from the tips and stems, on the 


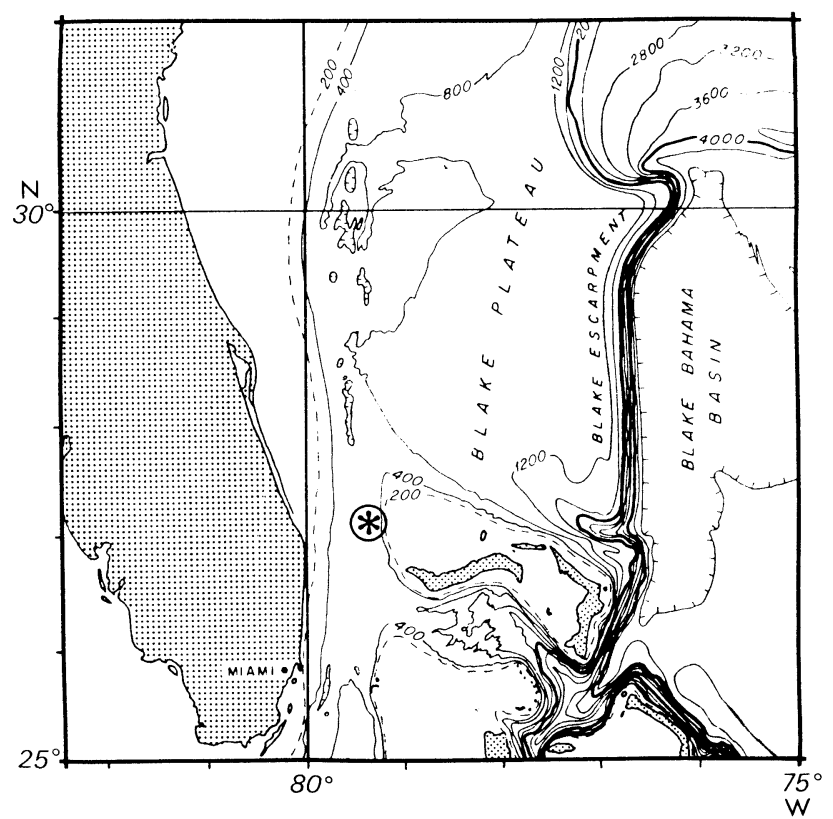

Fig 1. Map of the collection site $\left({ }^{*}\right)$ of the deep-sea corals in the Gulf Stream off Florida

TABLE 1

Description of deep-sea corals used in this project

\begin{tabular}{lcccc}
\hline Sample name & Alvin dive no & Depth $(\mathrm{m})$ & Size & Composition \\
\hline Gerardia & 1278 & 632 & $1.3 \mathrm{~m}$ diam & Organic \\
Corallium noibe & 1273 & 640 & $1.3 \mathrm{~m} \mathrm{diam}$ & Calcite \\
Paragorgia johnsoni & 1274 & 616 & $80 \times 50 \mathrm{~cm}$ & Calcite \\
Lophelia & 1273 & 640 & $\sim 15 \mathrm{~cm}$ long & Aragonite
\end{tabular}

basis of diameter. The 5 tip and stem samples ranged in average diameter from $0.6-6 \mathrm{~mm} ; 5$ layers were peeled off the trunk. Layers 4 and 5 (innermost) were thicker $(1.75 \mathrm{~mm})$ than layers $1-3(1 \mathrm{~mm})$. Due to the difficulty of removing an even thickness of subsequent layers, 2/3 of the coral trunk (averaged $20 \mathrm{~mm}$ diam) still remained. The layers were cleaned of calcium carbonate with $1 \mathrm{~N} \mathrm{HCl}$, then rinsed thoroughly with distilled water. The Gerardia samples were combusted using conventional techniques reported previously (Griffin \& Druffel, 1985).

The Corallium samples were cleaned aboard ship using a $1 \%$ solution of clorox in sea water. At the WHOI laboratory, tips $<1 \mathrm{~mm}$ in diameter were snipped off the coral with wire cutters. The trunk of the coral $(35 \mathrm{~mm}$ diameter) was sliced radially with a rock saw, and the individual slices were photographed directly onto photographic paper with an enlarger. Bands were clearly discernible (Fig 4); 11 bands were selected that could be identified throughout the circumference of the trunk. They were marked directly onto the coral, which was then sectioned with a small Dremel saw. All of the Corallium samples were acidified using conventional techniques. 
Fig 2. Sketch of Gerardia showing tree-like structure and build up of layers in trunk section
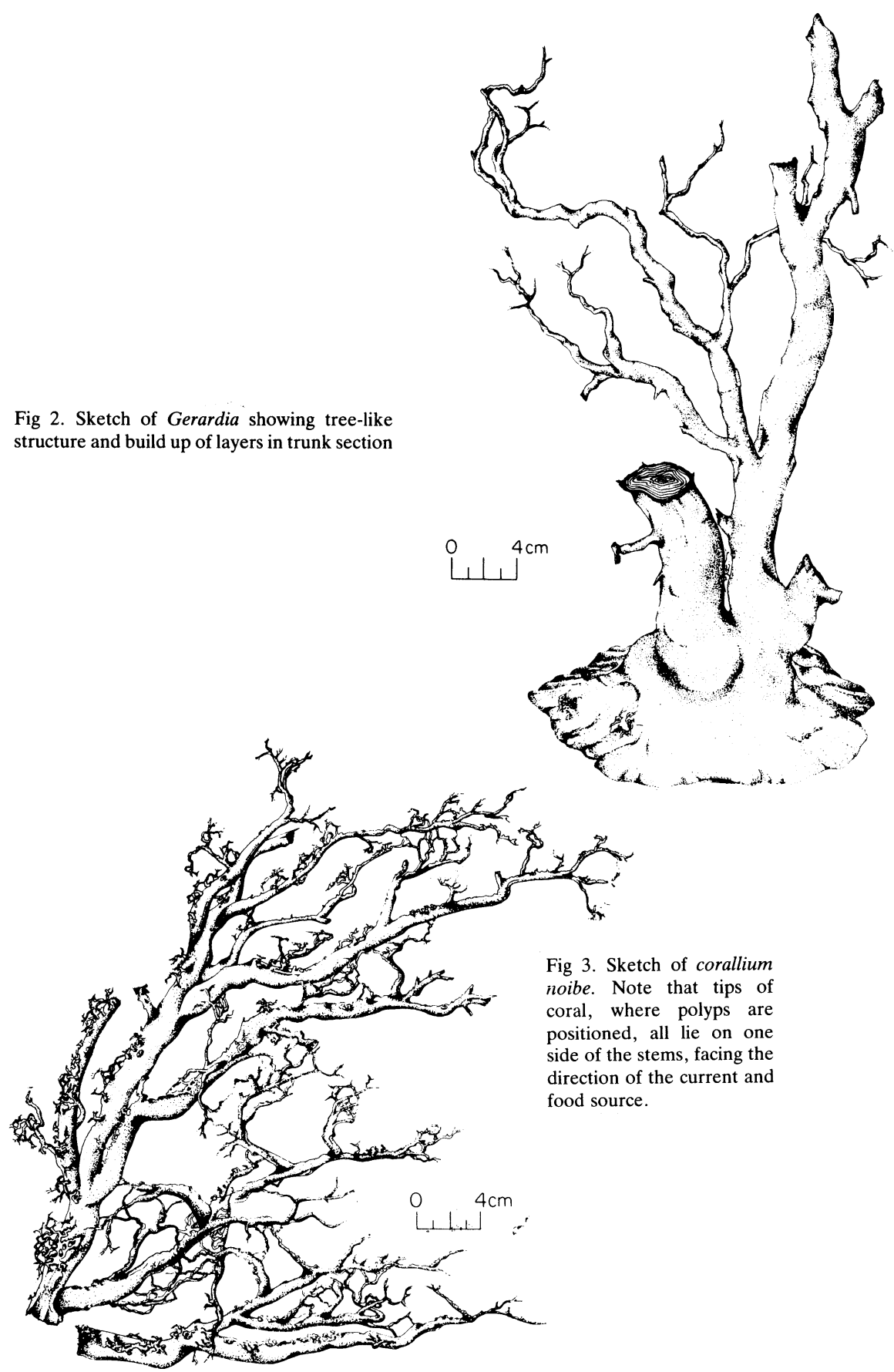

Fig 3. Sketch of corallium

noibe. Note that tips of

coral, where polyps are

positioned, all lie on one

side of the stems, facing the

direction of the current and

food source. 


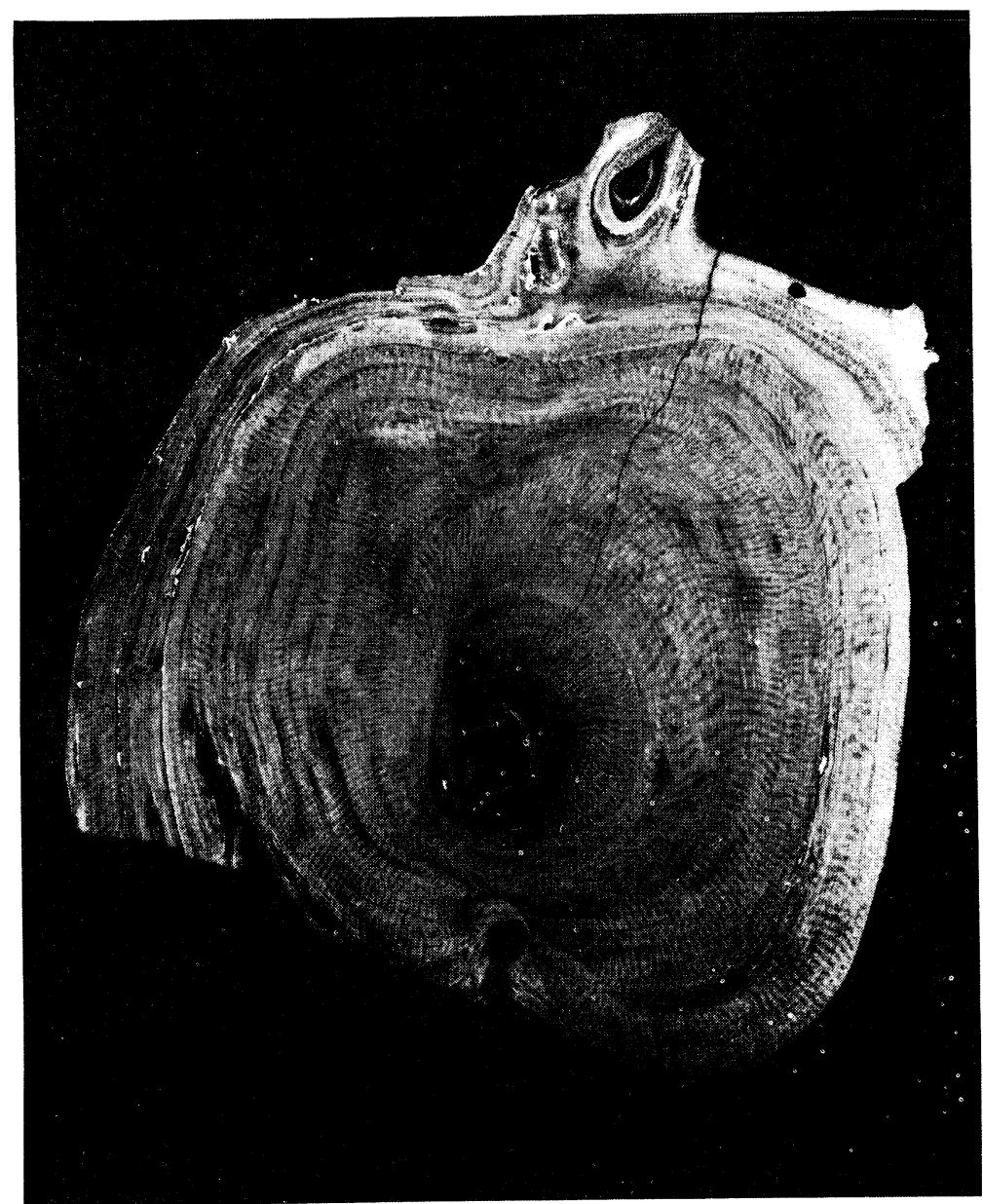

Fig 4. Photograph of a thin section, taken using an enlarger, of a radial slice of the Corallium noibe trunk

The porous nature of the Paragorgia johnsoni specimen, led us to suspect that using a basic cleaning solution (clorox) would lead to contamination by extraneous $\mathrm{CO}_{2}$. Thus, the samples were soaked in $0.1 \mathrm{~N} \mathrm{HCl}$, the polyps brushed off and the cleaned skeleton rinsed thoroughly with distilled water. Two samples from the tips $(0-2.5 \mathrm{~mm}), 1$ from the stems $(2.5-$ $4.0 \mathrm{~mm}$ ) and 1 from the entire diameter of the trunk, were analyzed for ${ }^{14} \mathrm{C}$. One of the smaller tip samples was combusted and the other Paragorgia samples were acidified.

The Lophelia specimens consisted of aragonite, as opposed to the calcitic composition of the other calcareous specimens. Both the brown and the white Lophelia are from the same piece of coral, which was attached to the 
Corallium specimen. Supposedly, the brown specimen was diagenetically altered when collected. Both Lophelia samples were cleaned in $1 \mathrm{~N} \mathrm{HCl}$ and acidified in a similar manner to the Paragorgia samples.

${ }^{14} \mathrm{C}$ analyses were performed on 31 samples, which include duplicates for the Corallium bands 6-1 and 5. $\mathrm{CO}_{2}$ gas was counted in a $200 \mathrm{~cm}^{3}$ copper gas proportional counter at $900 \mathrm{~mm} \mathrm{Hg}$ and $21^{\circ} \mathrm{C}$ (an average of 4 6-day periods/sample). All the Corallium samples were counted as $\mathrm{CO}_{2}$, as were the smallest Gerardia tip $(0-1.2 \mathrm{~mm})$ and the two smallest Paragorgia tip (0$2.5 \mathrm{~mm}$ ) samples. The remaining samples were counted as acetylene gas in 1.51 and $0.75 \mathrm{~L}$ quartz gas proportional counters. These samples were counted for an average of 42 -day periods. $\Delta^{14} \mathrm{C}$ was calculated using the convention of Stuiver and Polach (1977). $\delta^{13} \mathrm{C}$ measurements were made on each $\mathrm{CO}_{2}$ sample (acetylene samples were reburned to $\mathrm{CO}_{2}$ ) using a VG Micromass $602 \mathrm{E}$ mass spectrometer according to methods previously described (Druffel, 1982).

\section{RESULTS AND DISCUSSION}

Radiocarbon measurements obtained for the four types of corals are shown in Table 2. The results for the Gerardia are derived from tips/stems and from trunk layers (Fig 5A, B). The $\Delta^{14} \mathrm{C}$ measurement of the smallest tip sample $(0-1.2 \mathrm{~mm}$ diam $)$ shows clearly the presence of bomb ${ }^{14} \mathrm{C}(+58 \pm$ $13 \%)$ within the skeleton. Larger diameter sections of the stems reveal $\Delta^{14} \mathrm{C}$ values (range $-47 \%$ to $-102 \%$ ) representative of prebomb levels present in the subsurface waters of the North Atlantic (Broecker et al, 1960; Stuiver \& Ostlund, 1980).

The layers from the Gerardia reveal a wide range of $\Delta^{14} \mathrm{C}$ values, from $-76 \%$ (L-1) to $-189 \%$ o (L-5). When plotted $v s$ average distance from the outside or growing edge of the trunk, a least squares fit of the $\Delta^{14} \mathrm{C}$ results reveals a highly significant linear relationship $(\mathrm{N}=5, \mathrm{r}=0.994$, Fig 5B). If this decrease in $\Delta^{14} \mathrm{C}$ was simply a function of age, it would mean that the coral was $>3000$ yr old, which would translate into a radial growth rate for the trunk of $0.005 \mathrm{~mm} / \mathrm{yr}$. This is far slower than the fairly rapid growth of the stems with diameters between 1 and $6 \mathrm{~mm}$ (Fig 5A).

Several assumptions have to be made before ${ }^{14} \mathrm{C}$ data can be used to calculate growth rate of deep-sea corals: 1$)$ radial growth rate ( $\mathrm{mm}$ diam/yr) was constant during the period of observation, 2) there was no incorporation of bomb ${ }^{14} \mathrm{C}$ into the trunk skeleton, and 3$){ }^{14} \mathrm{C} /{ }^{12} \mathrm{C}$ ratio of the carbon supplied to the skeleton remained constant throughout the life of the coral.

First, although the thickness of layers in the trunk of the coral are approximately equal $(1 \mathrm{~mm})$, we have no independent evidence, other than the linearity of the ${ }^{14} \mathrm{C}$ results, that shows that the radial growth rate was constant during any period of the skeletal formation. Second, in view of the similarity between L-1 and the stem samples (except for the tips), it is likely that the assumption regarding no bomb ${ }^{14} \mathrm{C}$ is valid. Third, the source of carbon to the skeletons of deep-sea corals, especially those that accrete an organic matrix, is largely unknown. The presence of bomb ${ }^{14} \mathrm{C}$ in the tips sample indicates that there is a surface-derived component (ie, phytoplankton, fecal pellets, marine snow) in their diet that eventually becomes part of 
TABLE 2

${ }^{14} \mathrm{C}$ measurements of deep-sea corals. $\delta^{13} \mathrm{C}$ results are of $\mathrm{CO}_{2}$ for the small samples and reburned acetylene for the larger samples (see text).

\begin{tabular}{|c|c|c|c|c|c|c|c|}
\hline $\begin{array}{c}\text { Woods } \\
\text { Hole } \\
\text { no. }\end{array}$ & Sample & $\Delta^{14} \mathrm{C}$ & $\pm 1 \sigma$ & $\begin{array}{c}\text { Organic/ } \\
\text { inorganic } \\
\text { carbon }\end{array}$ & $\delta^{13} \mathrm{C}$ & $\begin{array}{l}\text { Average stem } \\
\text { diameter } \\
(\mathrm{mm})\end{array}$ & $\begin{array}{l}\text { Average distance } \\
\text { from trunk edge } \\
(\mathrm{mm})\end{array}$ \\
\hline & Gerardia & & & & & & \\
\hline 202 & $0-1.2 \mathrm{~mm}$ & +58 & 13 & 0 & -17.93 & 0.6 & \\
\hline 143 & $1.2-2.5 \mathrm{~mm}$ & -54 & 5 & 0 & -17.15 & 1.2 & \\
\hline 203 & $2.5-3.5 \mathrm{~mm}$ & -102 & 6 & 0 & -16.93 & 3.0 & \\
\hline 155 & $3.5-5.0 \mathrm{~mm}$ & -35 & 2.8 & 0 & -16.31 & 4.2 & \\
\hline 169 & $5.0-6.0 \mathrm{~mm}$ & -88 & 4 & 0 & -16.32 & 5.5 & \\
\hline 197 & $\mathrm{~L}-1$ & -76 & 4 & 0 & -16.17 & & 0.5 \\
\hline 198 & $\mathrm{~L}-2$ & -96 & 3 & 0 & -16.31 & & 1.5 \\
\hline 199 & $\mathrm{~L}-3$ & -111 & 4 & 0 & -15.90 & & 2.5 \\
\hline 200 & $\mathrm{~L}-4$ & -142 & 2.7 & 0 & -16.02 & & 3.9 \\
\hline \multirow[t]{2}{*}{201} & $\mathrm{~L}-5$ & -189 & 2.9 & 0 & -16.03 & & 5.6 \\
\hline & Paragorgia johns & & & & & & \\
\hline 146 & $0-2.5 \mathrm{~mm}$ & +60 & 18 & 0 & -10.23 & 1.2 & \\
\hline 205 & $0-2.5 \mathrm{~mm}$ & -60 & 14 & I & -3.53 & 1.2 & \\
\hline 204 & $2.5-4.0 \mathrm{~mm}$ & -69 & 4 & I & -3.77 & 3.2 & \\
\hline \multirow[t]{2}{*}{168} & trunk & -72 & 4 & I & -3.68 & & 25.0 \\
\hline & Lophelia & & & & & & \\
\hline 192 & (white) & -63 & 5 & I & -1.01 & 8.0 & \\
\hline 193 & (brown) & -75 & 4 & I & -0.77 & 8.0 & \\
\hline 554 & $\begin{array}{l}\text { Corallium noibe } \\
\text { tips }\end{array}$ & -84 & 10 & I & -6.57 & 0.5 & \\
\hline 555 & band 8 & -74 & 13 & I & -3.19 & & 0.4 \\
\hline 558 & band 7 & -78 & 11 & I & -3.10 & & 1.1 \\
\hline 556 & band 6-1 dup. & -87 & 9 & I & -1.92 & & 2.1 \\
\hline 557 & band 6-1 & -85 & 9 & I & -4.34 & & 2.1 \\
\hline 583 & band 6-2 & -74 & 8 & I & -3.95 & & 3.0 \\
\hline 581 & band 5 dup. & -90 & 11 & I & -1.94 & & 4.3 \\
\hline 560 & band 5 & -100 & 9 & I & -0.19 & & 4.3 \\
\hline 616 & band 4 & -89 & 8 & I & -4.71 & & 5.7 \\
\hline 582 & band 3-1 & -81 & 8 & I & -4.47 & & 7.4 \\
\hline 615 & band 3-2 & -83 & 8 & I & -3.91 & & 9.3 \\
\hline 613 & band $2-1$ & -87 & 7 & I & -3.76 & & 11.5 \\
\hline 614 & band $2-2$ & -88 & 10 & I & -3.59 & & 14.1 \\
\hline 617 & band 1 & -100 & 9 & I & -2.62 & & 17.4 \\
\hline
\end{tabular}

the skeletal matrix. There is the possibility that they also incorporate carbon from other sources, such as sediments or dissolved or particulate organic matter in sea water, the ${ }^{14} \mathrm{C}$ signatures of which are considerably older than the surface-derived material (Emerson et al, 1987; Williams \& Druffel, 1987). However, large variations in the incorporation of this older carbon 


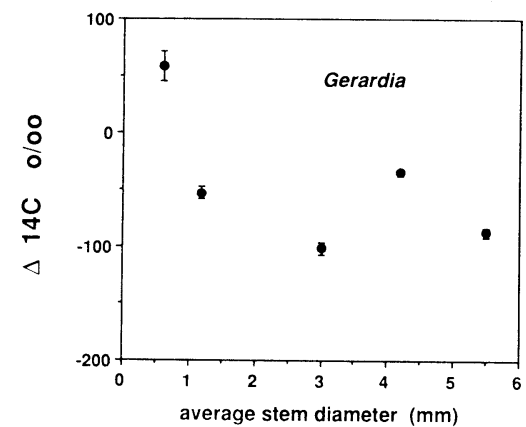

Fig 5A. Radiocarbon results of the Gerardia in the tip and stem samples $v s$ average diameter $(\mathrm{mm})$. Bomb radiocarbon is clearly present in the smallest sample.

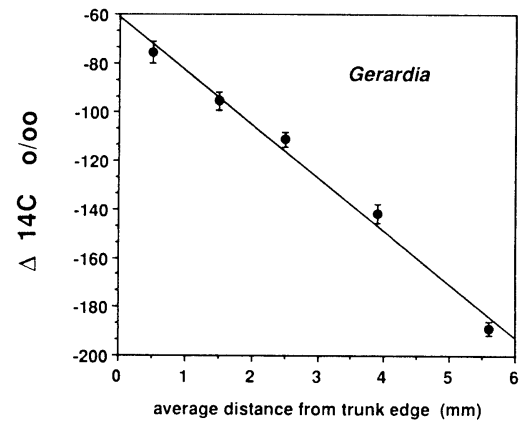

Fig 5B. Radiocarbon results of the Gerardia trunk layers $v s$ average diameter of the layers $(\mathrm{mm})$. A least-squares fit of the results is shown by the line (see text for details).

would have to be envisioned to obtain the very low $\Delta^{14} \mathrm{C}$ values observed in $\mathrm{L}-4$ and L-5. The $\delta^{13} \mathrm{C}$ results resemble typical values observed in living marine organic matter (Table 2). Clearly, $\Delta^{14} \mathrm{C}$ analyses are needed from the interior of the Gerardia trunk (6-12mm from trunk edge) to determine whether the values continue to decrease with the observed slope. Measurements of other radioisotopes present in trace quantities $\left(i e,{ }^{210} \mathrm{~Pb}\right.$, possibly ${ }^{230} \mathrm{Th}$ ) might also be useful for establishing whether or not the coral is indeed millennia old.

Layers from the Corallium noibe trunk show a range of $\Delta^{14} \mathrm{C}$ values from -100 to $-74 \%$ o (Fig 6). A least-squares fit of these data $(\mathrm{N}=13)$ reveals a decrease of $15 \pm 10 \%$ o $(90 \%$ confidence limits) from the outer edge $(0 \mathrm{~mm})$ to the center of the trunk $(17.5 \mathrm{~mm})$. The range of $\Delta^{14} \mathrm{C}$ data from the outer layers $(-74$ to $-87 \%$ ) is indistinguishable from values measured during GEOSECS on water samples from the same density surface $(\sigma-\Theta=27.38)$ and latitude (Stations 31 and 33) in the North Atlantic (Stuiver \& Ostlund, 1980). This similarity, in addition to the $\delta^{13} \mathrm{C}$ values (Table 2) that resemble those observed in DIC (Kroopnick, 1985), strongly suggest that the source of carbon to Corallium noibe is DIC from sea water at the depth where the coral grew.

Before a direct correlation between the observed $\Delta^{14} \mathrm{C}$ decrease $(15 \pm$ $10 \%$ ) and age is made, a re-examination of the assumptions discussed above is necessary. First, excess ${ }^{210} \mathrm{~Pb}$ concentrations in samples from the outer $8 \mathrm{~mm}$ of this coral skeleton indicate that the growth rate was constant (Druffel \& King, ms in preparation). Second, the $\Delta^{14} \mathrm{C}$ measurement from the outer layers do not show the presence of bomb ${ }^{14} \mathrm{C}$ (Stuiver \& Ostlund, 1980). Third, it is reasonable to assume that the ${ }^{14} \mathrm{C} /{ }^{12} \mathrm{C}$ ratio of the DIC in North Atlantic subsurface sea water has been constant over the past several centuries, in view of constant $\Delta^{14} \mathrm{C}$ values observed $( \pm 10 \%)$ in surface corals from the Florida Straits (Druffel, 1982). Based on these assumptions and the $15 \%$ decrease, a radial growth rate of $0.13 \mathrm{~mm} / \mathrm{yr}$ is calculated for the trunk and an age of $135 \pm 90 \mathrm{yr}$ is inferred. This is within the limits of the growth rate calculated from excess ${ }^{210} \mathrm{~Pb}$, or $250 \pm 50$ yr (Druffel \& King, ms in preparation). 


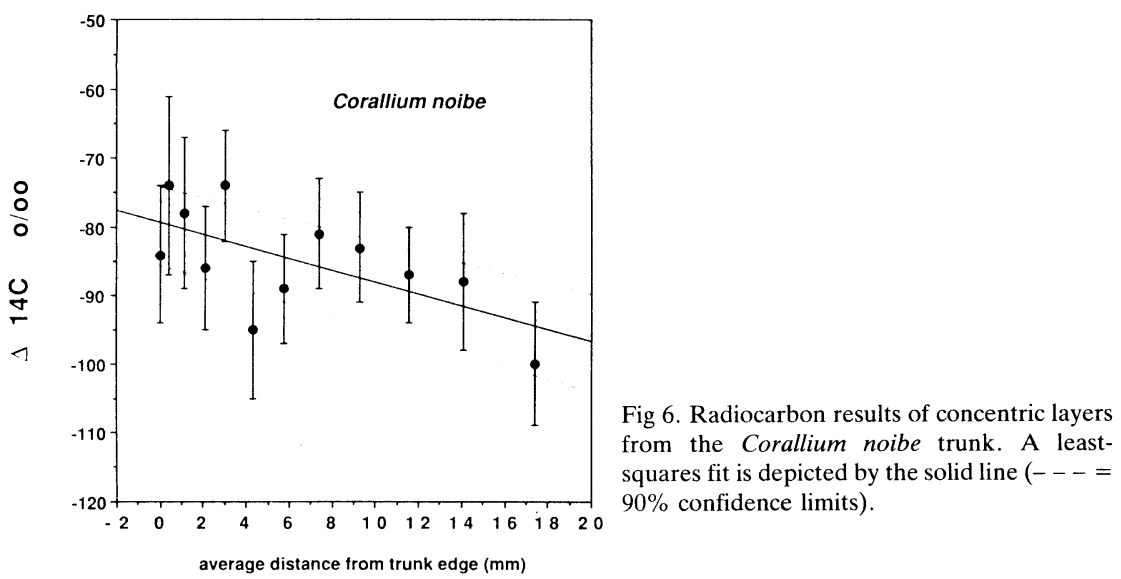

The $\Delta^{14} \mathrm{C}$ measurements of Paragorgia johnsoni reveal prebomb values for the inorganic carbon $(-60$ to $-72 \%$ ) and a postbomb value for the organic carbon in the tips $(+60 \%)$. These results follow trends observed in the Corallium and Gerardia samples, where the source of organic carbon to deep-sea corals is, for the most part, from the surface ocean and that of the calcium carbonate is DIC from sea water. The usefulness of Paragorgia is limited, however, due to its porous structure and the possibility of calcareous accretion within the inner portion of the skeleton (Ted Bayer, pers commun, 1983).

The Lophelia results were similar for the two specimens. We examined any alteration of the $\Delta^{14} \mathrm{C}$ signal in a sample that had been diagenetically altered (brown), with respect to the pristine sample (white). The results are the same within error, indicating no effect on the $\Delta^{14} \mathrm{C}$ or $\delta^{13} \mathrm{C}$ signature.

In summary, we conclude that the primary source of carbon to calcareous deep-sea corals is DIC from the surrounding sea water. These corals can serve as recorders of the ${ }^{14} \mathrm{C} /{ }^{12} \mathrm{C}$ ratio of DIC at depth in the ocean. Corals with skeletons that contain organic matter have significant surface-derived carbon incorporated into their skeletons. These results provide evidence to support the contention that deep-sea corals can be used to obtain time histories of numerous transient $\left(\right.$ bomb $\left.{ }^{14} \mathrm{C},{ }^{90} \mathrm{Sr}, \mathrm{Pu}\right)$ and nontransient $\left({ }^{18} \mathrm{O} /{ }^{16} \mathrm{O},{ }^{13} \mathrm{C} /{ }^{12} \mathrm{C},{ }^{210} \mathrm{~Pb}\right)$ tracers in the deep ocean. For example, ventilation of the main thermocline can be studied in three dimensions using time histories of bomb ${ }^{14} \mathrm{C}$ and ${ }^{90} \mathrm{Sr}$. Sampling remains a difficulty however. Submersibles are the least destructive means for collection, but they are also particularly restrictive in availability and cost. Archived specimens do exist and we believe that feasibility studies similar to the one reported here will further manifest their potential as recorders of deep-sea processes.

\section{ACKNOWLEDGMENTS}

We are grateful to the captain and crew of the $R / V$ Lulu and $D S R / V$ Alvin for their dedication to the success of this project, to the chief scientist, Conrad Neumann, to Elisabeth Sikes and especially to Ralph Hollis whose skill in maneuvering Alvin is superb. We thank Ted Bayer and Ricky Grigg 
for identifying the corals and William Spitzer for his work on the Corallium specimen during the initial stages of the project. We also acknowledge the help of Linda King with various aspects of this project. We are indebted to Mike Bacon, Amy Witter and Elisabeth Sikes for helpful reviews of the manuscript. We are grateful to NSF for funding this project through grants OCE83-15260 and OCE86-08263. WHOI Contribution No. 6992.

\section{REFERENCES}

Broecker, W S, Gerard, R, Ewing, M and Heezen, B C, 1960, Natural radiocarbon in the Atlantic Ocean: Jour Research, v 65, p 2903-2931.

Druffel, E R M, 1982, Banded corals: changes in oceanic carbon-14 during the Little Ice Age: Science, v 218, p 13-19.

Druffel, E R M and King, L (ms), Corals as recorders of chemical properties in the deep sea: Ms in preparation.

Druffel, E R M and Linick, T W, 1978, Radiocarbon in annual coral rings from Florida: Geophys Research Letters, v 5, p 913-916.

Duncan, P M, 1877, On the rapidity of growth and variability of some Madreporaria on an Atlantic cable with remarks upon the rate of accumulation of foraminiferal deposits: Ann Mag Nat Hist, ser 4, v 20, p 361-365.

Emerson, S C, Stump, C, Grootes, P, Stuiver, M, Farwell, G and Schmidt, F, 1987, Estimates of degradable organic carbon in deep-sea surface sediments from ${ }^{14} \mathrm{C}$ concentrations: Nature, v 329, p 51-53.

Goreau, T F and Goreau, N I, 1960, The physiology of skeleton formation in corals, IV, On isotopic equilibrium exchanges of calcium between corallium and environment in living and deep reef-building corals: Biol Bull Marine Biol Lab, Woods Hole, v 119, p 416-427.

Griffin, S and Druffel, E R M, 1985, Woods Hole Oceanographic Institution Radiocarbon Laboratory: Sample treatment and gas preparation: Radiocarbon, v 27, no. 1, p 43-51.

Grigg, R W, 1974, Distribution and abundance of precious corals in Hawaii, in Cameron, A M, ed, Internatl coral reef symposium, 2nd, Proc: Brisbane, Australia, v 2, p 235-240.

Kroopnik, P M, 1985, The distribution of ${ }^{13} \mathrm{C}$ of $\Sigma \mathrm{CO}_{2}$ in the world oceans: Deep-sea Research, v 32 , no. 1, p $57-84$.

Mikkelsen, N, Erlenkeuser, E, Killingley, J S and Berger, W H, 1982, Norwegian corals: radiocarbon and stable isotopes in Lophelia pertusa: Boreas, $\mathrm{v} 11, \mathrm{p}$ 163-171.

Mullins, H T, Newton, C R, Heath, K and Vanburen, H M, 1981, Modern deep-water coral mounds north of Little Bahama Bank: Criteria for recognition of deep-water biotherms in the rock record: Jour Sed Petrol, v 51, no. 3, p 999-1013.

Neumann, A C, Kofold, J W and Keller, G H, 1977, Lithoherms in the Straits of Florida: Geology, v 5, p 4-10.

Newton, C R, Mullins, H T, Garduski, A F, Hine, A C and Dix, G R, 1987, Coral mounds on the West Florida Slope: Unanswered questions regarding the development of deep-water banks: Soc Economic Paleontologists \& Mineralogists, Research Repts, p 359-367.

Pourtales, L F, 1868, Contributions to the Gulf Stream at great depths: Bull Mus Comp Zool, Harvard, v 1, p 103-142.

Pratje, O, 1924, Korallenbänke in tiefen und kühlen Wässer: Centralbl f Min Geol, p 410-415.

Schuhmacher, $\mathrm{H}$ and Zibrowius, H, 1985, What is hermatypic? A redefinition of ecological groups in corals and other organisms: Coral Reefs, v 4, p 1-9.

Sikes, E, (ms) 1984, Bioerosion of deep carbonates by macro-endoliths: Masters's thesis, Univ North Carolina, $120 \mathrm{p}$.

Squires, D F, 1964, Fossil coral thickets in Wairarapa, New Zealand: Jour Paleontol, v 38, no. 5, p 904-915.

Stuiver, M and Ostlund, H G, 1980, GEOSECS Atlantic radiocarbon: Radiocarbon, v 22, no. $1, \mathrm{p} 1-24$.

Stuiver, M and Polach, H A, 1977, Discussion: Reporting of ${ }^{14} \mathrm{C}$ data: Radiocarbon, v 19, no. 3 , p 355-363.

Teichert, C, 1958, Cold and deep-water coral banks: Bull Am Assoc Petrol Geol, v 42, no. 5, p 1064-1082. 
Vaughan, T W and Wells, J G, 1943, Revision of the suborders, families and genera of the Schleractinia: Geol Soc America Spec Paper, v 144, p 1-363.

Wells, J G, 1956, Scleractinia. Treatise on invertebrate paleontology, Part F, Coelenterata, in Moore, R C, ed, Geol Soc America, Univ Kansas, p 328-444.

Williams, P M and Druffel, E R M, 1987, Radiocarbon in dissolved organic matter in the Central North Pacific Ocean: Nature, v 330, no. 6145, p 246-248. 